\title{
Two Principles of Reticular Chemistry Uncovered in a Metal-Organic Framework of Heterotritopic Linkers and Infinite Secondary Building Units
}

\author{
Noelle R. Catarineu, ${ }^{\dagger}$ Alexander Schoedel, ${ }^{\dagger}$ Philipp Urban, ${ }^{\dagger}$ Maureen B. Morla, ${ }^{\dagger}$ \\ Christopher A. Trickett, ${ }^{\dagger}$ and Omar M. Yaghi ${ }^{\dagger, \ddagger} * *$ \\ ${ }^{\dagger}$ Department of Chemistry, University of California, Berkeley; Materials Sciences Division, \\ Lawrence Berkeley National Laboratory; Kavli Energy NanoSciences Institute at Berkeley \\ ${ }^{\ddagger}$ King Fahd University of Petroleum and Minerals, Dhahran 34464, Saudi Arabia \\ *To whom correspondence should be addressed: yaghi@berkeley.edu
}

\section{Table of Contents}

$\begin{array}{ll}\text { General Information } & \text { S2 } \\ \text { Synthesis of Heterotritopic Linker } & \text { S3 - S7 } \\ \text { Synthesis of MOF-910 } & \text { S7 - S9 } \\ \text { Scanning Electron Microscopy } & \text { S9 } \\ \text { Single Crystal X-ray Diffraction } & \text { S9 - S10 } \\ \text { Powder X-ray Diffraction Patterns } & \text { S11- S12 } \\ \text { Electron Paramagnetic Resonance Spectrum } & \text { S12 } \\ \text { Infrared Spectra } & \text { S13 } \\ \text { Thermogravimetric Analysis } & \text { S14 } \\ \text { N } 2 \text { Adsorption Isotherm } & \text { S15 } \\ \text { Pore Size Distribution } & \text { S15 } \\ \text { Multi-point BET Surface Area Plot } & \text { S16 } \\ \text { Optical Microscopy } & \text { S16 } \\ \text { References } & \text { S17 }\end{array}$




\section{General Information}

\section{Materials}

All starting materials, reagents and solvents were used without further purification. Anhydrous $N, N$-dimethylformamide (DMF, purity $\geq 99.8 \%$ ), anhydrous dichloromethane (DCM, purity $\geq 99.8 \%$ ), and anhydrous methanol (MeOH, purity $\geq 99.8 \%$ ) were obtained from EMD Millipore Chemicals; anhydrous acetone (purity $\geq 99.8 \%$ ) was obtained from Acros Organics; toluene (purity $\geq 99.5 \%$ ); zinc chloride (purity $\geq 98 \%$ ), 1,3,5-tribromobenzene (purity = 98\%), 4-methoxycarbonylphenylboronic acid, 3,4-dimethoxyphenylboronic acid (purity $\geq 95 \%$ ), 2-benzyloxy-5-pyridineboronic acid pinacol ester (purity $=97 \%$ ), triethylamine (purity $\geq 99.5 \%$ ), hydrobromic acid (48\% aqueous solution), and palladium on carbon (extent of labeling: $10 \mathrm{wt}$. \%) were obtained from Sigma-Aldrich. Tetrabutylammonium bromide (purity $=99 \%$ ) and tetrakis(triphenylphosphine)palladium $(0)$ (purity $=99 \%$ ) were obtained from Strem Chemicals.

\section{Analytical techniques}

Single-crystal X-ray diffraction data were collected with synchrotron radiation at Beamline 11.3.1 of the Advanced Light Source, Lawrence Berkeley National Laboratory. Powder X-ray diffraction (PXRD) patterns were collected with a scan speed of $0.5 \mathrm{~s} / \mathrm{step}$ and a step size of $0.030^{\circ}$ in $2 \theta$ on a Bruker D8-Advance $\theta-\theta$ diffractometer in reflectance geometry employing $\mathrm{Cu}$ $\mathrm{K}_{\alpha}$ line radiation and parallel focusing Gobel mirrors operated at $1600 \mathrm{~W}(40 \mathrm{kV}, 40 \mathrm{~mA})$ power and equipped with a Lynxeye PSD detector. Nuclear magnetic resonance spectra were acquired on a Bruker Avance-400 MHz or Avance-600 MHz NMR spectrometer. Chemical shifts are reported in ppm downfield of tetramethylsilane referenced to residual solvent peaks $\left(\mathrm{CHCl}_{3} ; \delta_{\mathrm{H}}=\right.$ 7.26 and $\delta_{\mathrm{C}}=77.2$, dimethylsulfoxide; $\delta_{\mathrm{H}}=2.50$ and $\delta_{\mathrm{C}}=39.5$ ). Multiplicities are reported with the following abbreviations: $\mathrm{s}=$ singlet, $\mathrm{d}=$ doublet, $\mathrm{t}=$ triplet, $\mathrm{q}=$ quartet, $\mathrm{m}=$ multiplet, $\mathrm{br}=$ broad resonance. Yields refer to isolated yields of compounds estimated to be $>95 \%$ pure as determined by ${ }^{1} \mathrm{H}$ NMR spectroscopy. Mass spectrometry data were obtained from the MicroMass/Analytical Facility operated by the College of Chemistry, University of California, Berkeley with a Thermo LTQ-FT spectrometer. Carbon, hydrogen, and nitrogen elemental microanalyses were performed in the Microanalytical Laboratory of the College of Chemistry, University of California, Berkeley with a Perkin Elmer 2400 Series II CHNS elemental analyzer. Scanning electron microscope (SEM) images were obtained with a FEI Quanta 3D FEG scanning electron microscope. SEM samples were prepared by direct deposition of a DCM dispersion of the MOF onto a silicon wafer. Low-pressure gas $\mathrm{N}_{2}$ adsorption isotherms were recorded on a Quantachrome Quadrasorb Evo gas sorption analyzer. Liquid nitrogen baths were used for measurements at $77 \mathrm{~K}$. Helium provided estimation of dead space for gas adsorption measurements. Ultra-high-purity grade $\mathrm{N}_{2}$ and He gases (Praxair, 99.999\% purity) were used throughout the adsorption experiments. Attenuated total reflectance (ATR) Fourier transform infrared (FTIR) spectra of neat samples were performed on a Bruker ALPHA Platinum ATR-FTI Spectrometer equipped with a single reflection diamond ATR module. Thermogravimetric analysis was performed with a TGA Q500 under an air flow of $60 \mathrm{~mL} \mathrm{~min}$. Electron paramagnetic resonance (EPR) spectra were collected at $9.26 \mathrm{GHz}$ (X-band) at room temperature with a Varian E-109 spectrometer equipped with an E-102 microwave bridge. Measurements were taken with $100 \mathrm{kHz}$ magnetic field modulation. 


\section{Synthesis and Characterization of Heterotritopic Linker}

\section{Synthesis of protected heterotritopic linker 1}

Scheme S1. One-pot, four-component Suzuki coupling reactions to afford 1.

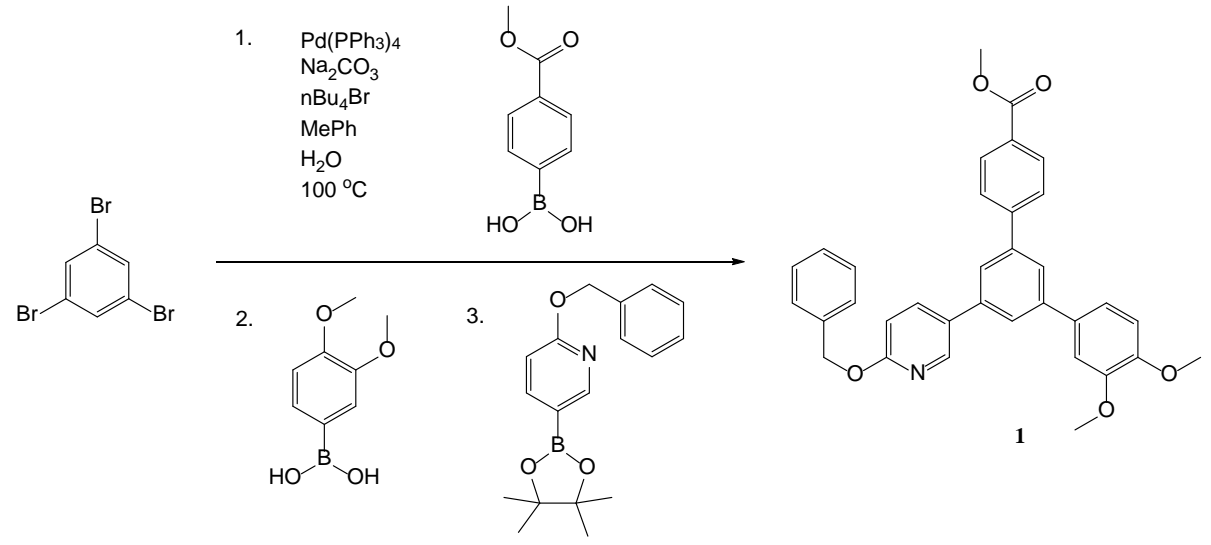

A three-necked round bottom flask was charged with 1,3,5-tribromobenzene (5.00 g, 15.9 mmol), 4-methoxycarbonylphenylboronic acid (3.50 g, $19.4 \mathrm{mmol})$, tetrabuylammonium bromide (1.03 g, $3.18 \mathrm{mmol})$, and toluene $(65.0 \mathrm{~mL})$. To this mixture was added a solution of sodium carbonate $(13.8 \mathrm{~g}, 130 \mathrm{mmol})$ in deionized water for a total volume of $65.0 \mathrm{~mL}$. The resulting mixture was degassed with $\mathrm{N}_{2}$ for 15 minutes before tetrakis(triphenylphosphine)palladium(0) (3.68 g mg, $3.18 \mathrm{mmol}$ ) was added. The reaction vessel was then sealed, and the mixture was degassed with $\mathrm{N}_{2}$ for another fifteen minutes. After heating at $100{ }^{\circ} \mathrm{C}$ for 14 hours under an atmosphere of $\mathrm{N}_{2}$, 3,4-dimethoxyphenylboronic acid (2.89 g, $15.9 \mathrm{mmol}$ ) was added. The reaction vessel was then sealed, and the mixture was degassed with $\mathrm{N}_{2}$ for 15 minutes. After heating at $100{ }^{\circ} \mathrm{C}$ for 10 hours under an atmosphere of $\mathrm{N}_{2}$, 2-benzyloxy5-pyridineboronic acid pinacol ester $(4.95 \mathrm{~g}, 15.9 \mathrm{mmol})$ was added. The reaction vessel was sealed, and the mixture was then degassed with $\mathrm{N}_{2}$ for 15 minutes. After heating at $100{ }^{\circ} \mathrm{C}$ for 14 hours under an atmosphere of $\mathrm{N}_{2}$, the mixture was allowed to cool to room temperature. The toluene layer was set aside, and the aqueous layer was washed twice with $50 \mathrm{~mL}$ of dichloromethane. The dichloromethane and toluene layers were each washed with brine, dried over anhydrous sodium sulfate, and filtered. The organic layers were then combined and concentrated. The resulting yellow oil was purified by flash column chromatography on silica gel eluting with 6:1 petroleum ether / ethyl acetate to obtain $1.46 \mathrm{~g}$ ( $17.3 \%$ yield) of the desired compound as a white foam: ${ }^{1} \mathrm{H}$ NMR $\left(400 \mathrm{MHz}, \mathrm{CDCl}_{3}\right) \delta 8.50(\mathrm{~d}, J=2.4 \mathrm{~Hz}, 1 \mathrm{H}), 8.15(\mathrm{~d}, J=$ $8.4 \mathrm{~Hz}, 2 \mathrm{H}), 7.91$ (dd, $J=2.4,8.6 \mathrm{~Hz}, 1 \mathrm{H}), 7.75$ (m, 3H), 7.70 (d, $J=6.4 \mathrm{~Hz}, 2 \mathrm{H}), 7.50$ (d, $J=$ $9.6 \mathrm{~Hz}, 2 \mathrm{H}$ ), 7.40 (t, $J=10.0 \mathrm{~Hz}, 3 \mathrm{H}), 7.34$ (d, $J=7.4 \mathrm{~Hz}, 1 \mathrm{H}), 7.23$ (d, $J=2.9 \mathrm{~Hz}, 1 \mathrm{H}), 7.17$ (d, $J=2.0 \mathrm{~Hz}, 1 \mathrm{H}), 7.00$ (d, $J=8.3 \mathrm{~Hz}, 1 \mathrm{H}), 6.93$ (d, $J=8.6 \mathrm{~Hz}, 1 \mathrm{H}) 5.45$ (s, 2H), 3.97 (s, 2H), 3.95 (s, 3H), 3.94 (s, 3H). ${ }^{13} \mathrm{C}$ NMR (100 MHz, CDCl3) $\delta 163.3,157.9,149.3,149.0$, 145.3,145.1, 142.7, 139.2 137.9, 137.1, 133.6, 132.6, 130.2, 128.4, 128.0, 127.8, 127.7, 127.3, 125.2, 125.0, 124.3, 119.7, 111.6, 111.3, 110.5, 67.9, 55.9, 52.5, 29.8; IR (ATR) v 3030, 2997, 2948, 1714, 1602, 1490, 1434, 1275, 1244, 1104, 1018, 770, 760, $698 \mathrm{~cm}^{-1}$; HRMS (ESI) calc. for $\left[\mathrm{C}_{34} \mathrm{H}_{30} \mathrm{O}_{5} \mathrm{~N}_{1}\right]^{+}$532.2118, found 532.2138. 


\section{Deprotection to linker precursor 2}

Scheme S2. Hydrogenolysis of benzyl protecting group to afford 2.
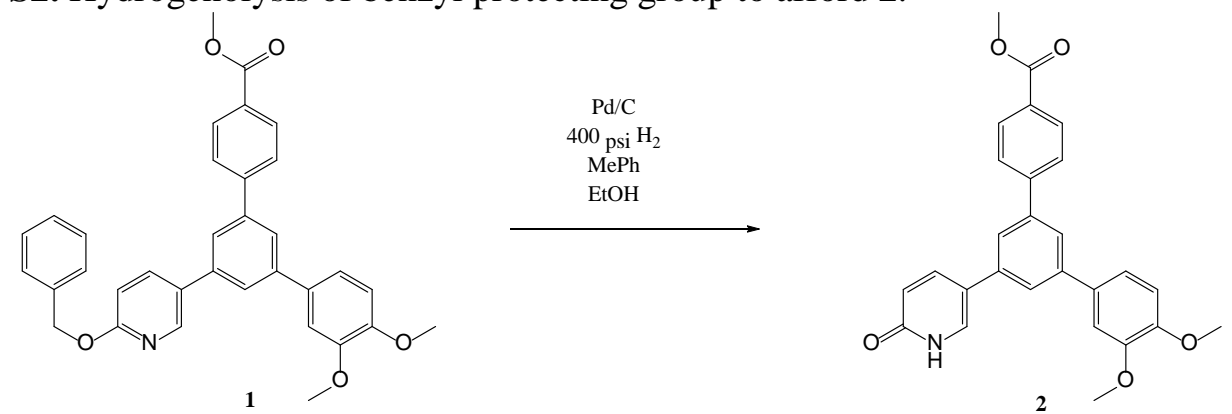

Compound 1 (1.46 g, $2.75 \mathrm{mmol}$ ) was dissolved in a 1:1 mixture of anhydrous toluene and absolute ethanol $(40.0 \mathrm{~mL})$. The clear solution was placed in a Parr bomb. The solution was degassed with $\mathrm{N}_{2}$ for fifteen minutes before palladium on carbon, $10 \mathrm{wt}$ \% $(198 \mathrm{mg}$ ) was added. The Parr bomb was sealed. The bomb was charged with $\mathrm{H}_{2}$ and vented three times before being pressurized to $400 \mathrm{psi}$. The mixture was stirred at $400 \mathrm{psi}$ for 14 hours at room temperature. The solvent was then removed under reduced pressure. The material was re-dissolved in dichloromethane and filtered through a plug of Celite. The filtrate was concentrated under reduced pressure, and the material was re-dissolved in a 1:1 mixture of hexanes / ethyl acetate. The solution was filtered through a plug of silica gel eluting with 1:1 hexanes / ethyl acetate followed by pure ethyl acetate. The filtrate was discarded. Finally, a solution of $20 \%$ methanol in dichloromethane eluted the desired compound. The filtrate was concentrated to give $1.12 \mathrm{~g}$ (92.0\% yield) of the desired compound as a brown waxy solid: ${ }^{\circ} \mathrm{C} .{ }^{1} \mathrm{H}$ NMR $\left(400 \mathrm{MHz}, \mathrm{CDCl}_{3}\right) \delta$ 8.15 (d, $J=8.2 \mathrm{~Hz}, 2 \mathrm{H}), 7.91$ (d, $J=9.2 \mathrm{~Hz}, 1 \mathrm{H}), 7.79$ (s, $1 \mathrm{H}), 7.73(\mathrm{~m}, 3 \mathrm{H}), 7.60$ (s, $2 \mathrm{H})$, 7.22 (d, $J=8.4 \mathrm{~Hz}, 1 \mathrm{H}), 7.16$ (s, 1H), 6.99 (d, $J=11.0 \mathrm{~Hz}, 1 \mathrm{H}), 6.75$ (d, $J=11.0 \mathrm{~Hz}, 1 \mathrm{H}) 3.99$ (s, 3H), 3.96 (s, 3H), 3.95 (s, 3H). ${ }^{13} \mathrm{C}$ NMR (100 MHz, CDCl3) $\delta 166.8,149.3,142.9,141.8,141.5$, 137.6, 134.6, 132.6, 130.2, 127.2, 125.0, 124.1, 123.3, 120.3, 119.7, 111.5, 110.5, 107.1, 56.1, 52.2, 29.7; IR (ATR) v 2950, 2930, 2835, 1714, 1655, 1275, 1244, 1103, 1024, 760, $701 \mathrm{~cm}^{-1}$; HRMS (ESI) calc. for $\left[\mathrm{C}_{27} \mathrm{H}_{22} \mathrm{O}_{5} \mathrm{~N}_{1}\right]^{-} 440.1503$, found 440.1504 .

\section{Deprotection to heterotritopic linker 3}

Scheme S3. Hydrolysis of methyl ester and methyl ether protecting groups to afford PBCP.<smiles>COC(=O)c1ccc(-c2cc(-c3ccc(=O)[nH]c3)cc(-c3ccc(OC)c(OC)c3)c2)cc1</smiles>

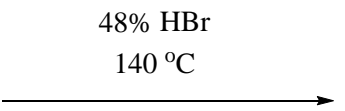

Compound 2 (1.12 mg, $2.54 \mathrm{mmol})$ and aqueous 48\% hydrobromic (100.0 mL) acid were combined in a round-bottom flask and heated at $140{ }^{\circ} \mathrm{C}$ for 6 hours. After cooling to room 
temperature, the mixture was diluted with deionized water $(100.0 \mathrm{~mL})$ and filtered. The filter cake was washed with deionized water $(300.0 \mathrm{~mL})$, dried, and collected to obtain $990 \mathrm{mg}(97.6 \%$ yield) of the desired compound as a white powder. ${ }^{1} \mathrm{H}$ NMR $\left(400 \mathrm{MHz}, \mathrm{DMSO}-d_{6}\right) \delta 9.15$ (s, $1 \mathrm{H}), 8.99$ (s, 1H), 8.04 (d, $J=8.4 \mathrm{~Hz}, 2 \mathrm{H}), 8.03$ (d, $J=9.6 \mathrm{~Hz}, 1 \mathrm{H}), 7.97$ (d, $J=8.8 \mathrm{~Hz}, 2 \mathrm{H}$ ), 7.77 (s, 1H), 7.73 (s, 1H), 7.70 (s, 1H), 7.21 (d, $J=2.4 \mathrm{~Hz}, 1 \mathrm{H}$ ), 7.14 (dd, $J=2.4,8.0 \mathrm{~Hz}, 1 \mathrm{H}$ ), $6.84(\mathrm{~d}, J=8.0 \mathrm{~Hz}, 1 \mathrm{H})$; $13 \mathrm{C}$ NMR $\left(125 \mathrm{MHz}, \mathrm{DMSO}-d_{6}\right) .{ }^{13} \mathrm{C}$ NMR $(100 \mathrm{MHz}, \mathrm{CDCl} 3) \delta$ 167.2, 162.0, 145.7, 145.6, 144.4, 142.0, 140.5, 140.3, 137.6, 133.5, 131.2, 129.9, 129.8, 127.3, 123.1, 123.0, 122.2, 120.0, 118.3, 117.8, 116.0, 114.5. IR (ATR) v 1690, 1654, 1609, 1592, 1548, 1517, 1407, 1318, 1274, 1179, 1120, 1093, 1017, 1000, 935, 844. 816, 766, 694, 588, 510, 507, 455. HRMS (ESI) calc. for $\left[\mathrm{C}_{24} \mathrm{H}_{16} \mathrm{O}_{5} \mathrm{~N}_{1}\right]^{-3} 38.1034$, found 398.1031.

\section{Nuclear magnetic resonance spectra of heterotritopic linker PBCP}

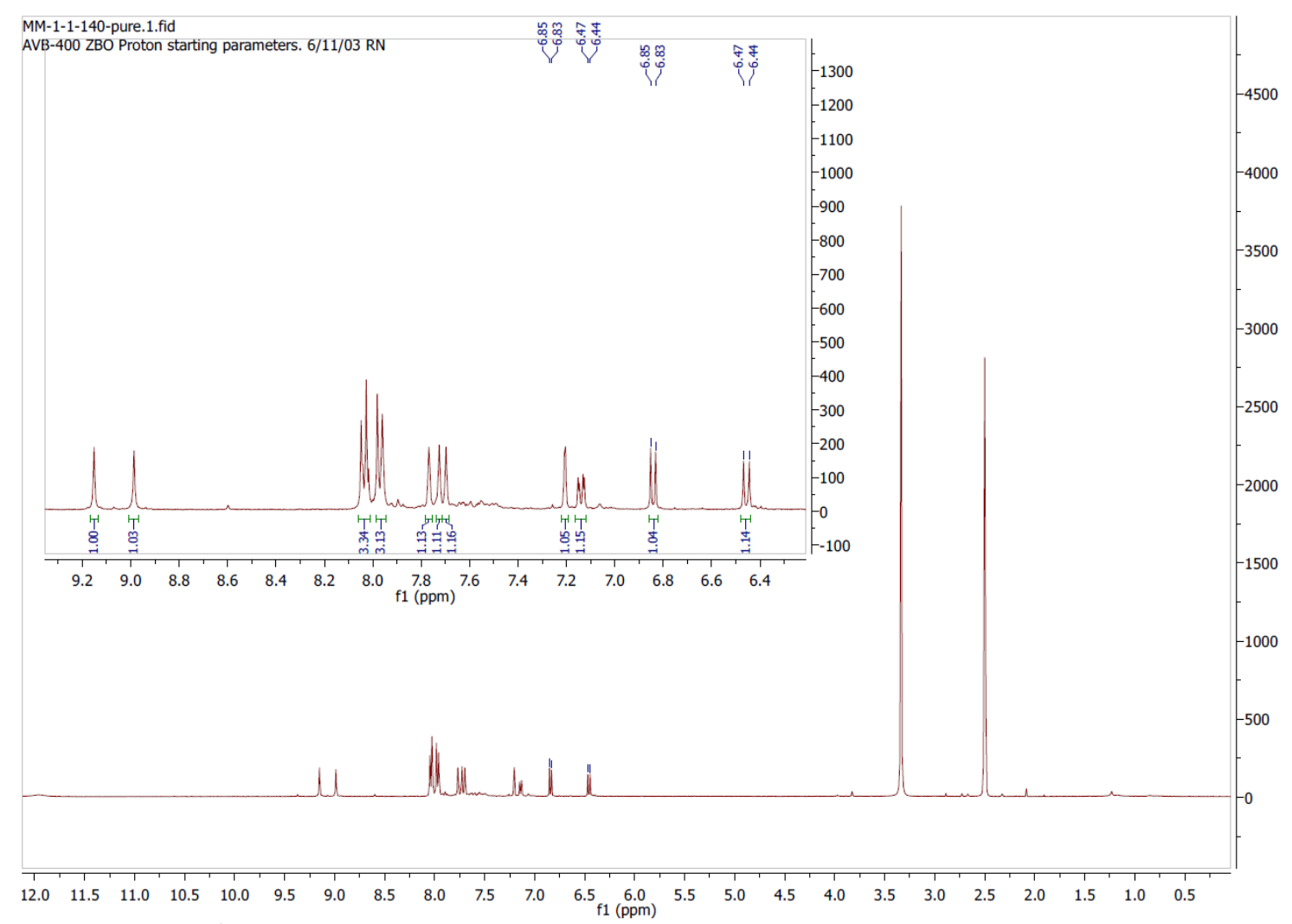

Figure S1. $1 \mathrm{D}{ }^{1} \mathrm{H}$ NMR spectrum of heterotritopic linker PBCP measured as a DMSO- $d_{6}$ solution. 


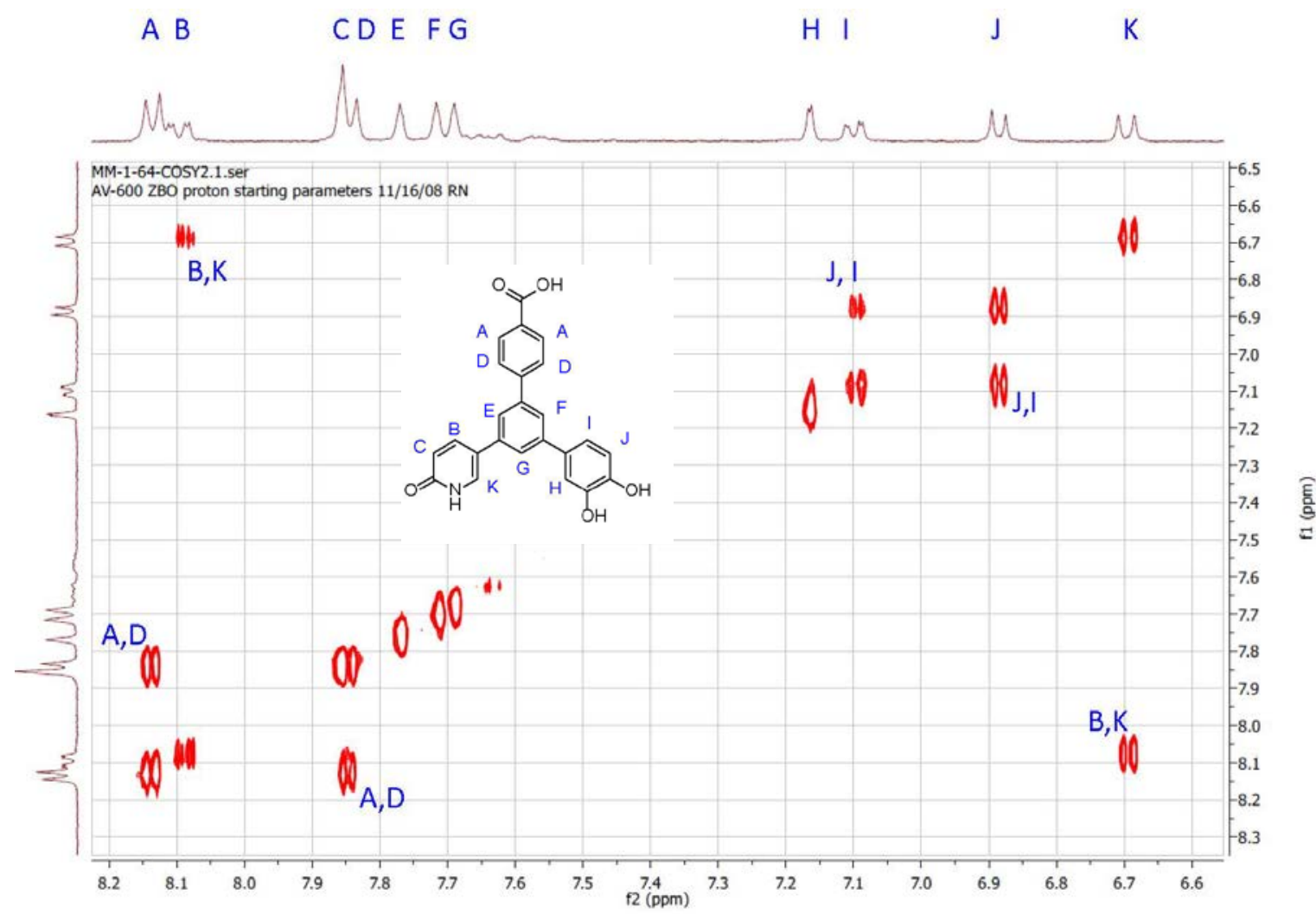

Figure S2. ${ }^{1} \mathrm{H}-{ }^{1} \mathrm{H}$ COSY $2 \mathrm{D}$ NMR spectrum of heterotritopic linker PBCP measured as a methanol- $d_{4}$ solution.

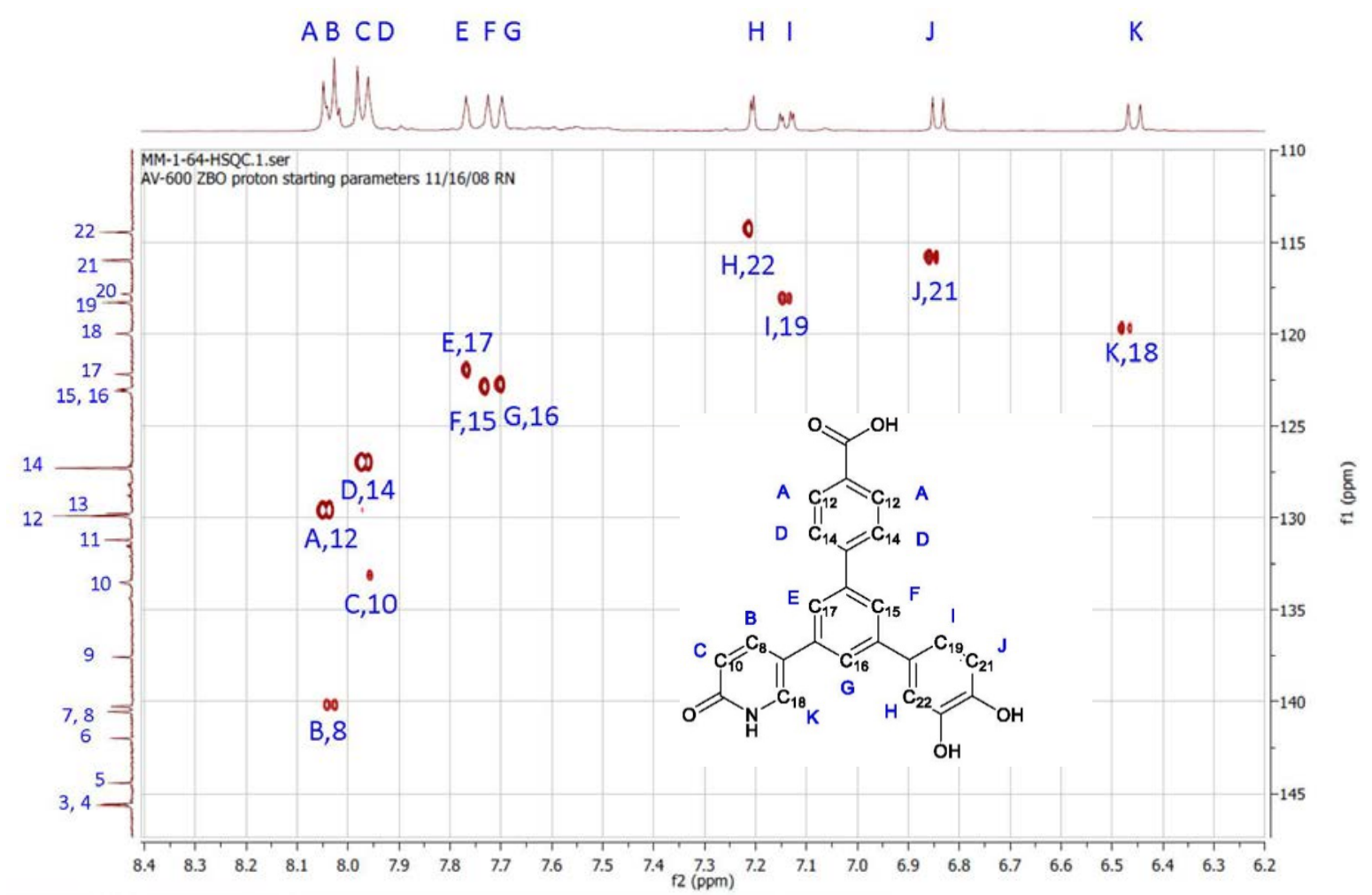

Figure S3. ${ }^{1} \mathrm{H}^{13} \mathrm{C}$ HSQC 2D NMR spectrum of heterotritopic linker PBCP measured as a 
DMSO- $d_{6}$ solution.

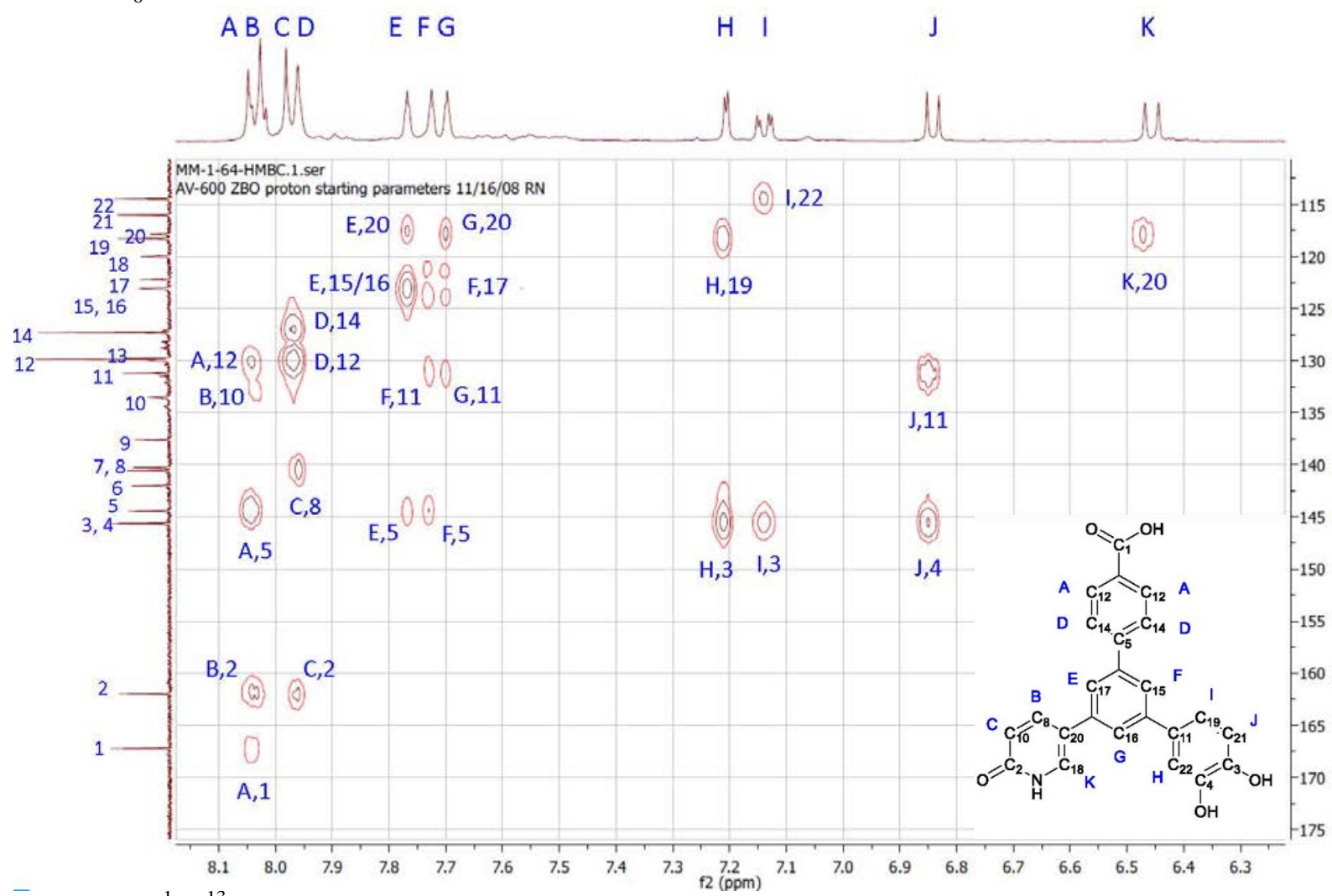

Figure S4. ${ }^{1} \mathrm{H}-{ }^{13} \mathrm{C}$ HMBC $2 \mathrm{D}$ NMR spectrum of heterotritopic linker PBCP measured as a DMSO- $d_{6}$ solution.

\section{Synthesis of MOF-910}

Scheme S4. Solvothermal synthesis of MOF-910 from heterotritopic linker PBCP and zinc(II) chloride.

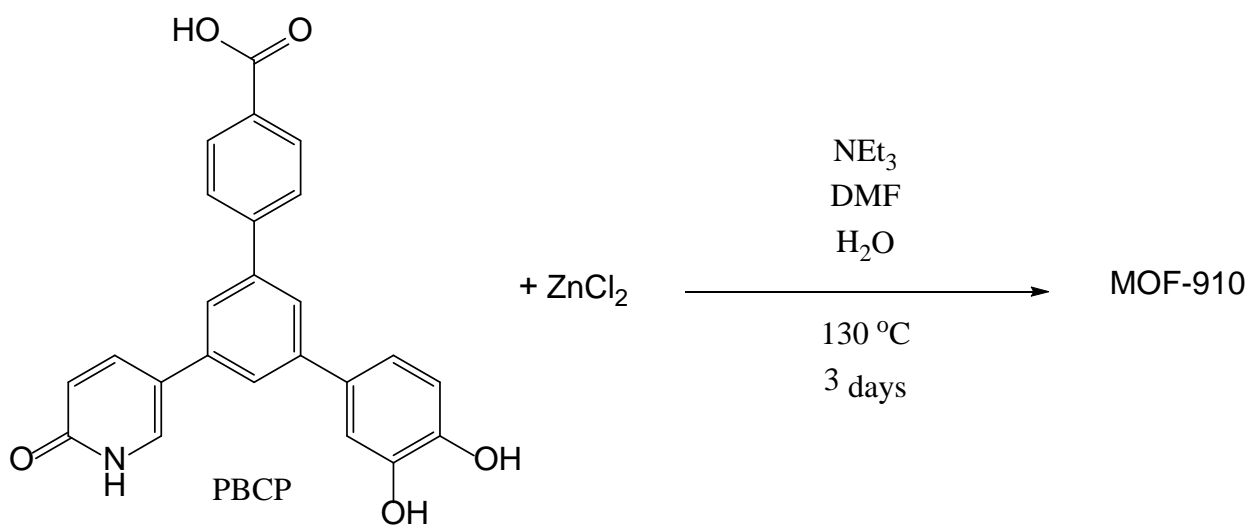

Zinc(II) chloride (90.0 mg, $0.660 \mathrm{mmol}$ ) and heterotritopic linker PBCP (30.0 mg, $0.0751 \mathrm{mmol}$ ) were added to a $20 \mathrm{~mL}$ scintillation vial and dissolved in DMF $(12.0 \mathrm{~mL})$. Deionized water (3.0 $\mathrm{mL}$ ) was added followed by triethylamine $(7.5 \mu \mathrm{L})$. The vial was capped and the mixture was sonicated for ten minutes before being heated at $130{ }^{\circ} \mathrm{C}$ in an oven for 3 days. After cooling to room temperature, the solvent was carefully removed by pipette and replaced with anhydrous DMF. The DMF was replaced with fresh anhydrous DMF once each day for 3 days. After 
sonicating for 30 seconds, the suspension was centrifuged and the supernatant removed by pipette and replaced with fresh anhydrous DMF. This process was repeated twice. The DMF was then replaced with anhydrous DCM by pipette. The DCM was replaced with fresh anhydrous DCM once each day for 3 days. The DCM was decanted, and the MOF crystals were placed in a Tousimis Samdri PVT-30 critical point dryer equipped with bone-dry $\mathrm{CO}_{2}$. The chamber was filled with liquid $\mathrm{CO}_{2}$, purged, and refilled 10 times. Finally, the chamber was filled with liquid $\mathrm{CO}_{2}$, heated to $40{ }^{\circ} \mathrm{C}$, and bled over 14 hours until atmospheric pressure was reached. The material was then heated at $120^{\circ} \mathrm{C}$ for 48 hours under 30 mTorr dynamic vacuum to give $38 \mathrm{mg}$ (48\% yield) of activated MOF-910 $\left.\left(\mathrm{Zn}_{3}(\mathrm{PBSP})\right)_{2}, \mathrm{Zn}_{3} \mathrm{C}_{48} \mathrm{H}_{26} \mathrm{O}_{10} \mathrm{~N}_{2}\right) .{ }^{1} \mathrm{H}$ NMR (500 MHz, DMSO$\left.d_{6}\right) \delta 8.25(\mathrm{dd}, J=2.4 \mathrm{~Hz}, J=9.2 \mathrm{~Hz}, 1 \mathrm{H}), 8.19(\mathrm{~d}, J=2.4 \mathrm{~Hz}, 1 \mathrm{H}), 8.04(\mathrm{~d}, J=8.4 \mathrm{~Hz}, 2 \mathrm{H})$, 7.97 (d, $J=8.4 \mathrm{~Hz}, 2 \mathrm{H}), 7.81$ (s, $1 \mathrm{H}), 7.77$ (s, 1H), 7.75 (s, 1H), 7.22 (d, $J=2.4 \mathrm{~Hz}, 1 \mathrm{H}), 7.15$ (dd, $J=2.4, J=8.4 \mathrm{~Hz}, 1 \mathrm{H}), 6.86(\mathrm{~d}, J=8.0 \mathrm{~Hz}, 1 \mathrm{H}), 6.71$ (d, $J=9.2 \mathrm{~Hz}, 1 \mathrm{H})$. Anal. calc. for $\mathrm{Zn}_{1.5} \mathrm{C}_{24} \mathrm{H}_{13} \mathrm{O}_{5} \mathrm{~N} \cdot 2 \mathrm{H}_{2} \mathrm{O}$ C: $56.36 \%$, H: $2.96 \%$, N: 2.74\%, found C: $54.48 \%, \mathrm{H}: 2.77 \%$, N: $3.09 \%$.

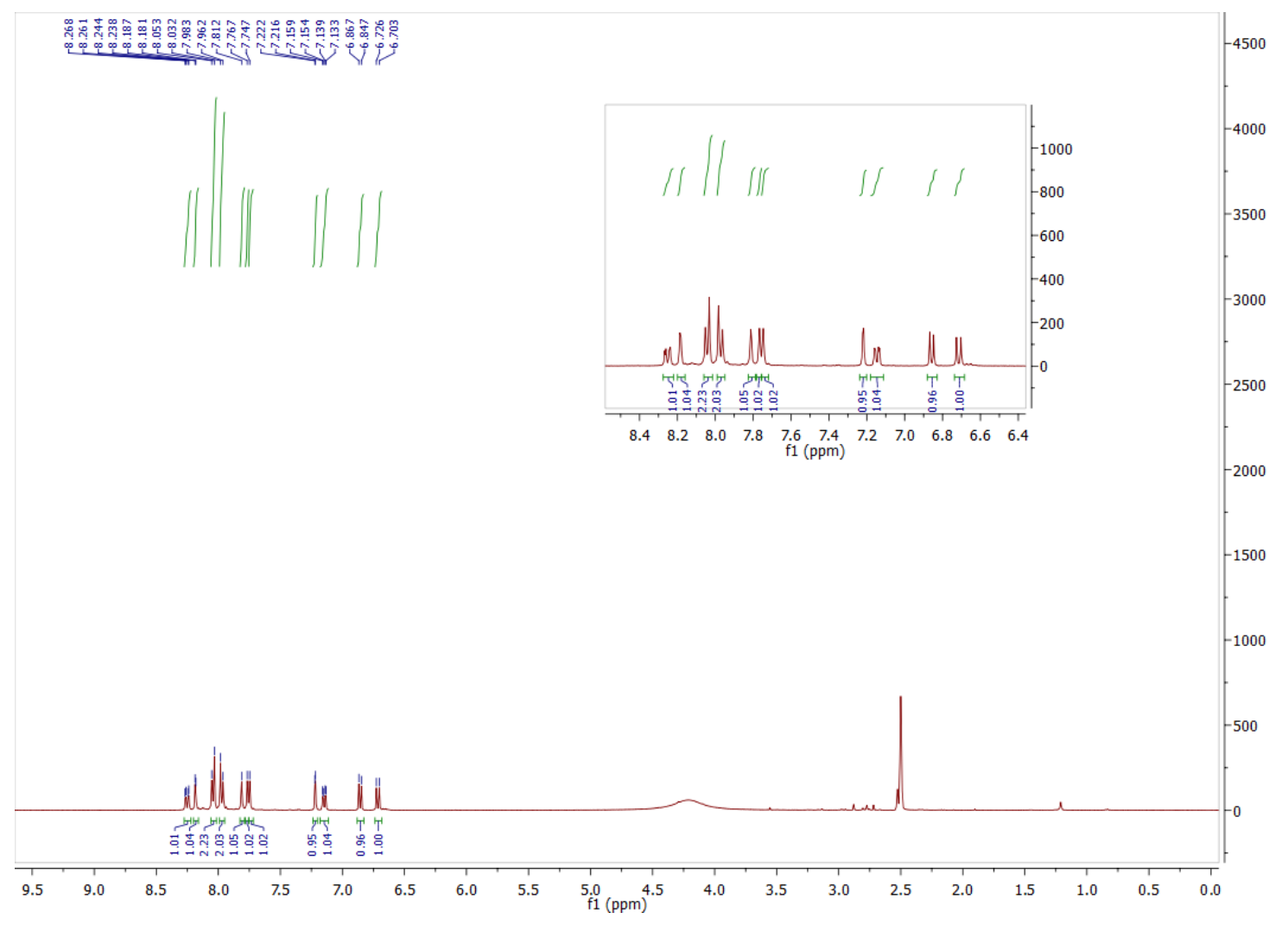

Figure S5. ${ }^{1} \mathrm{H}$ NMR spectrum of MOF-910 after dissolution in a mixture of DCl in DMSO- $d_{6}$.

Proton NMR spectroscopy of a sample of MOF-910 post-digestion agrees with the structure solved by X-ray diffraction. For solution phase NMR spectroscopy analysis, MOF-910 (5.0 mg) was dissolved in a solution of DCl $(10 \mu \mathrm{L})$ in DMSO- $d_{6}(500 \mu \mathrm{L})$. Since the resonances of the heteroatom protons are not visible in this acidic solvent mixture, all protons of the linker appear in the aromatic region (6.5 to $8.5 \mathrm{ppm}$ ) of the spectrum. The only significant peaks not originating from the linker result from the resonances of water and DMSO. The absence of any species in the NMR spectrum that might serve as counterions, such as triethylammonium or dimethylammonium, confirms the chemical composition as a neutral framework with a fully deprotonated trianionic linker. The two most downfield resonances appear at lower field in this spectrum than in the PBCP linker spectrum (Figure S1). 2D NMR experiments (Figures S2 - S4) established these two resonances as the vicinal protons of the pyridone moiety. The shift toward 
higher ppm is explained by protonation of the pyridone moiety by the DCl. The ${ }^{1} \mathrm{H}$ NMR spectrum of as-synthesized PBCP linker measured in the $10 \mu \mathrm{L} \mathrm{DCl} / 500 \mu \mathrm{L}$ DMSO solvent mixture corresponded with the above spectrum in chemical shift of the pyridone protons.

\section{Scanning Electron Microscopy}

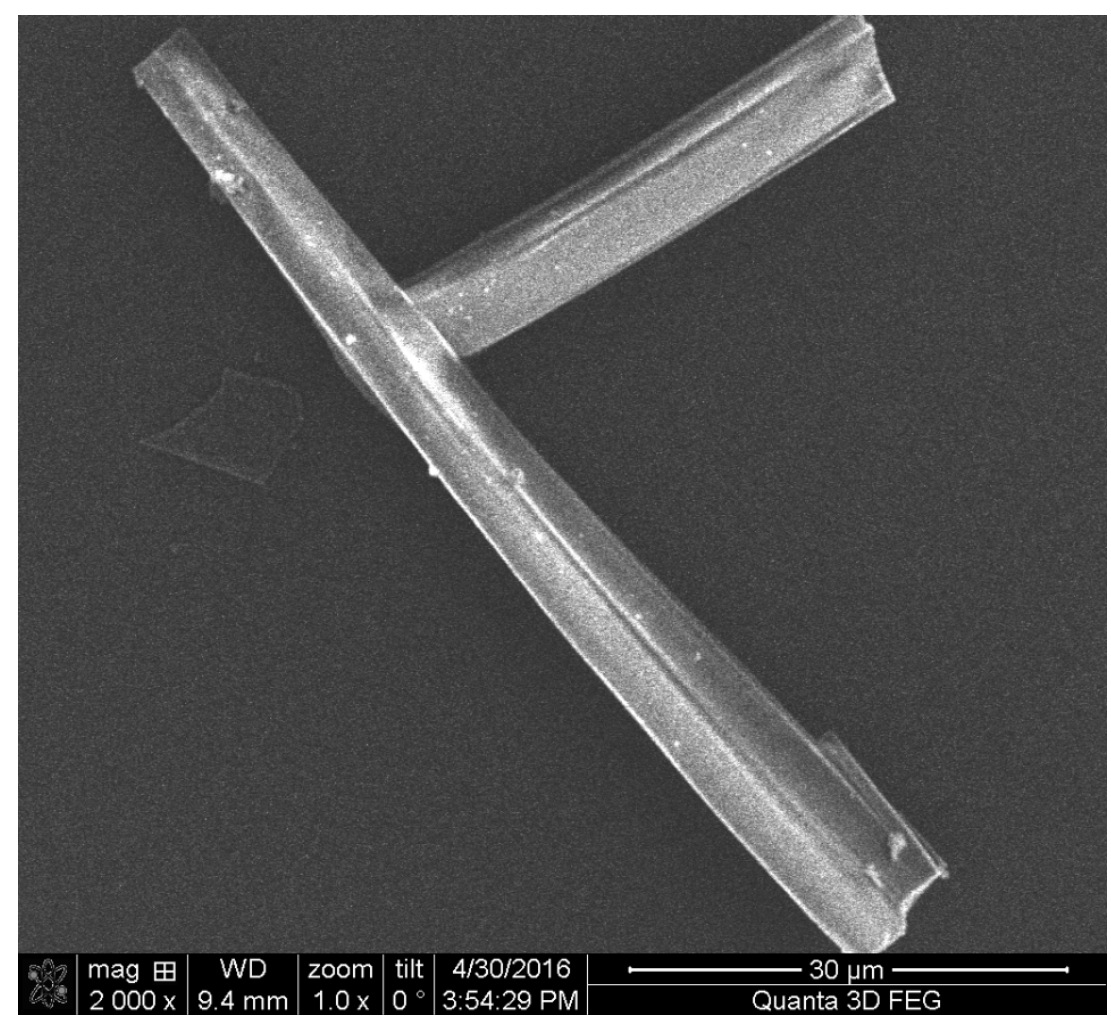

Figure S6. SEM image of MOF-910 crystals.

\section{Single Crystal X-ray Diffraction}

Single-crystal samples were mounted on MiTeGen ${ }^{\circledR}$ kapton loops and placed in a 260(2) K nitrogen cold stream provided by an Oxford Cryostream 700 Plus low temperature apparatus on the goniometer head of a Bruker D8 diffractometer equipped with a PHOTON100 CMOS detector operating in shutterless mode. Diffraction data were collected using synchrotron radiation monochromated with a silicon (111) reflection to a wavelength of 0.7749(1) $\AA$. Semiempirical absorption correction as well as scaling of the datasets was performed with SADABS ${ }^{1}$. Structure solution was performed with intrinsic phasing using SHELXT ${ }^{2}$ as implemented in $\mathrm{APEX}^{3}$. Least-squares structure refinements were performed using SHELXL ${ }^{4}$ as implemented in Olex2. For the disordered benzoate fragment of the structure, interatomic distances were restrained to their ideal values. ${ }^{6}$ One isotropic displacement parameter was refined for all atoms in the disordered fragment. Due to the resolution of the data $(1.2 \AA)$, a free refinement of the disordered benzoate fragment did not converge. Initial test refinement yielded a ratio between the two possible conformations of the benzoate moiety that was not significantly different from the ideal value of 0.5 , so the value was fixed at 0.5 for the final refinement. During structure refinement, contributions of the solvent to the diffraction intensities were masked with the 
method implemented in Olex2. ${ }^{7}$ The solvent-accessible portion of the structure was determined to be $71.7 \%$ of the volume; the contribution of 3002 electrons was masked. Crystallographic data for MOF-910 are summarized in Table S1.

Table S1. Crystal data and results of the structure refinement of MOF-910.

\begin{tabular}{|c|c|}
\hline Identification code & MOF-910 \\
\hline Formula & $\mathrm{Zn}_{1.5} \mathrm{C}_{24} \mathrm{H}_{13} \mathrm{O}_{5} \mathrm{~N}$ \\
\hline Formula weight $/ \mathrm{gmol}^{-1}$ & 493.41 \\
\hline Temperature / K & $260(2)$ \\
\hline \multirow[t]{3}{*}{ Lattice parameter / $\AA$} & $a=47.239(2)$ \\
\hline & $b=47.239(2)$ \\
\hline & $c=27.1216(12)$ \\
\hline Cell volume / $\AA^{3}$ & $52414(5)$ \\
\hline Crystal system & trigonal \\
\hline Space group & $R-3 c($ no. 167$)$ \\
\hline$\rho_{\text {calcd. }} / \mathrm{gcm}^{-3}$ & 0.563 \\
\hline Z & 36 \\
\hline$F(000)$ & 8964 \\
\hline$\lambda / \AA$ & 0.7749 \\
\hline Reflections (independent) & 95434 (3583) \\
\hline$R_{\text {int }} / R_{\sigma}$ & $0.1213 / 0.0293$ \\
\hline$\mu / \mathrm{mm}^{-1}$ & 0.802 \\
\hline $\max . \sin \theta / \lambda / \AA^{-1}$ & 0.4196 \\
\hline Absorption correction & semi-empirical \\
\hline Parameters / Restraints & $236 / 177$ \\
\hline Weighting scheme & $\begin{array}{l}w=1 /\left[\sigma^{2}\left(\mathrm{~F}_{\mathrm{o}}^{2}\right)+(0.1427 \mathrm{P})^{2}+146.7548 \mathrm{P}\right], \text { where } \\
\mathrm{P}=\left(\mathrm{F}_{\mathrm{o}}^{2}+2 \mathrm{~F}_{\mathrm{c}}^{2}\right) / 3\end{array}$ \\
\hline$R 1[I>2 \sigma(I)]$ & 0.0738 \\
\hline$R 1$ (all) & 0.0897 \\
\hline$w R 2[I>2 \sigma(I)]$ & 0.2186 \\
\hline$w R 2$ (all) & 0.2322 \\
\hline GooF (all) & 1.113 \\
\hline$\Delta \rho_{\text {max. }} / \Delta \rho_{\text {min. }} / \mathrm{e}^{-3}$ & $0.514 /-0.789$ \\
\hline
\end{tabular}




\section{Powder X-ray Diffraction (PXRD) Patterns}

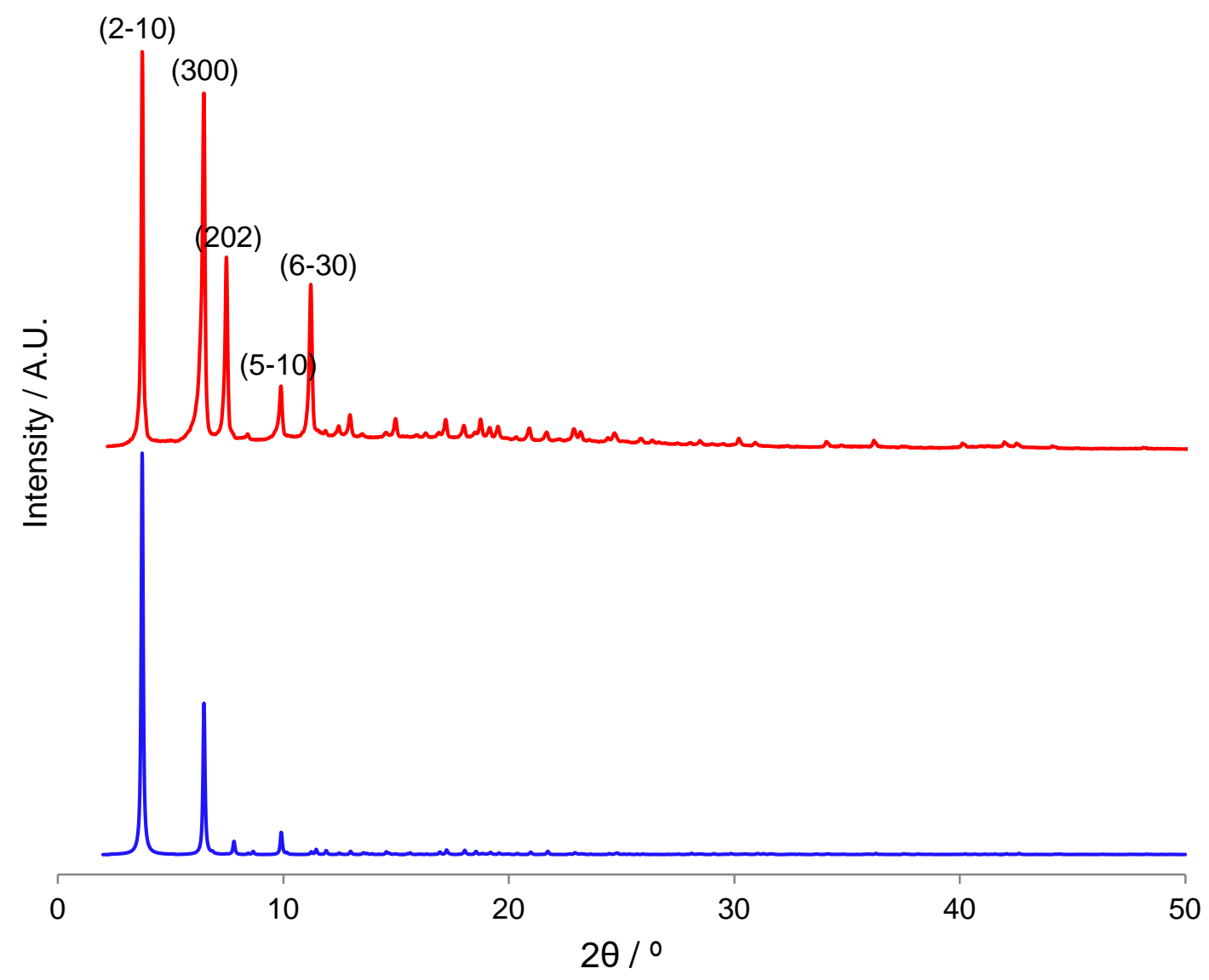

Figure S7. PXRD patterns of MOF-910. Experimental pattern (red) and pattern simulated from single-crystal X-ray data (blue).

Slight differences in the intensities between the experimental bulk phase pattern and the pattern calculated from the single-crystal model likely result from the preferred orientation of the long needle-shaped crystals measured for the bulk phase experimental pattern and the contribution of the solvent in the pores of the bulk experimental sample, which is not accounted for in the simulated pattern. 


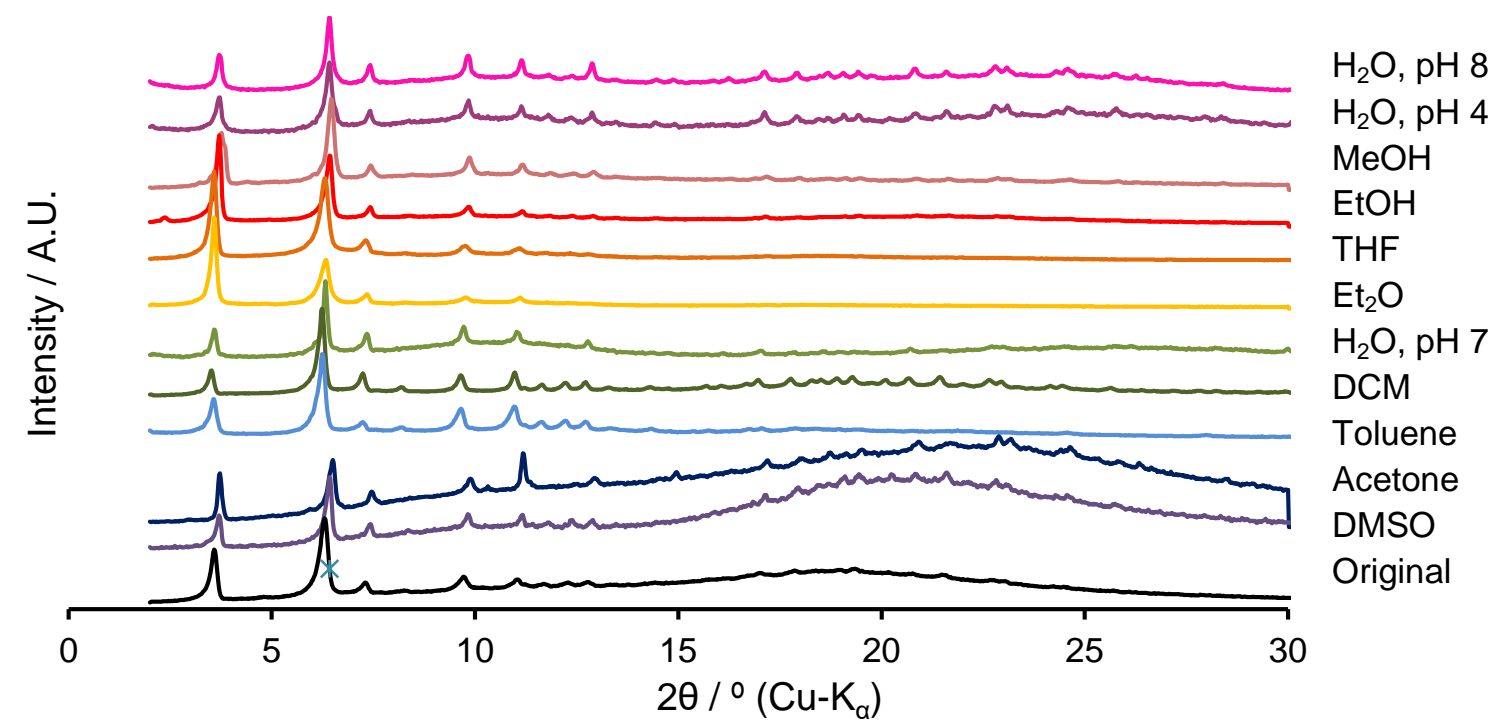

Figure S8. PXRD patterns of MOF-910 after 24 hours of immersion in various solvents.

\section{Electron Paramagnetic Resonance Spectrum}

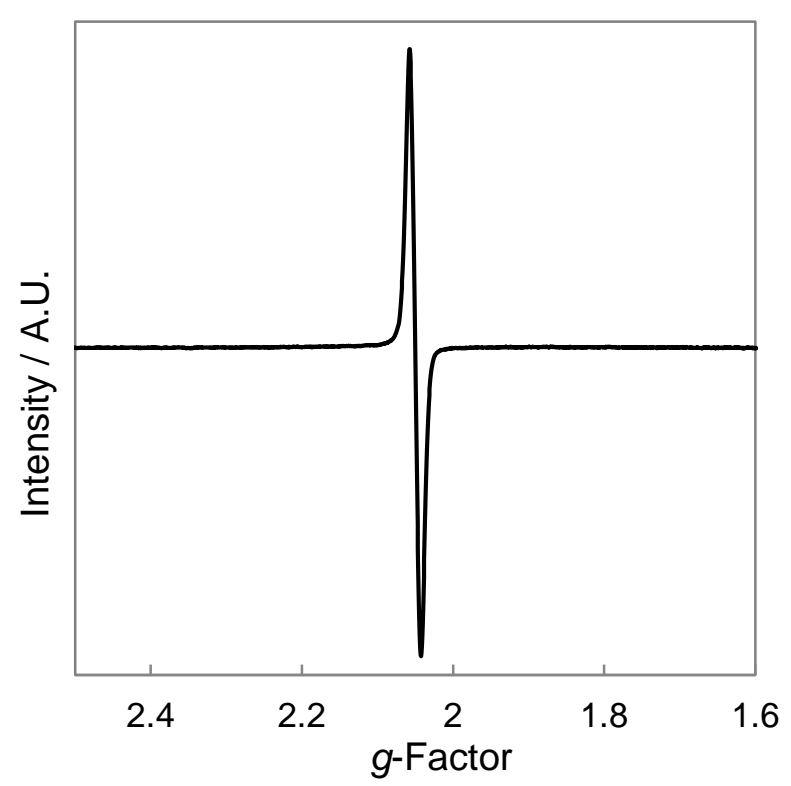

Figure S9. Solid-state EPR spectrum of MOF-910 measured at room temperature. 


\section{Infrared Spectra}

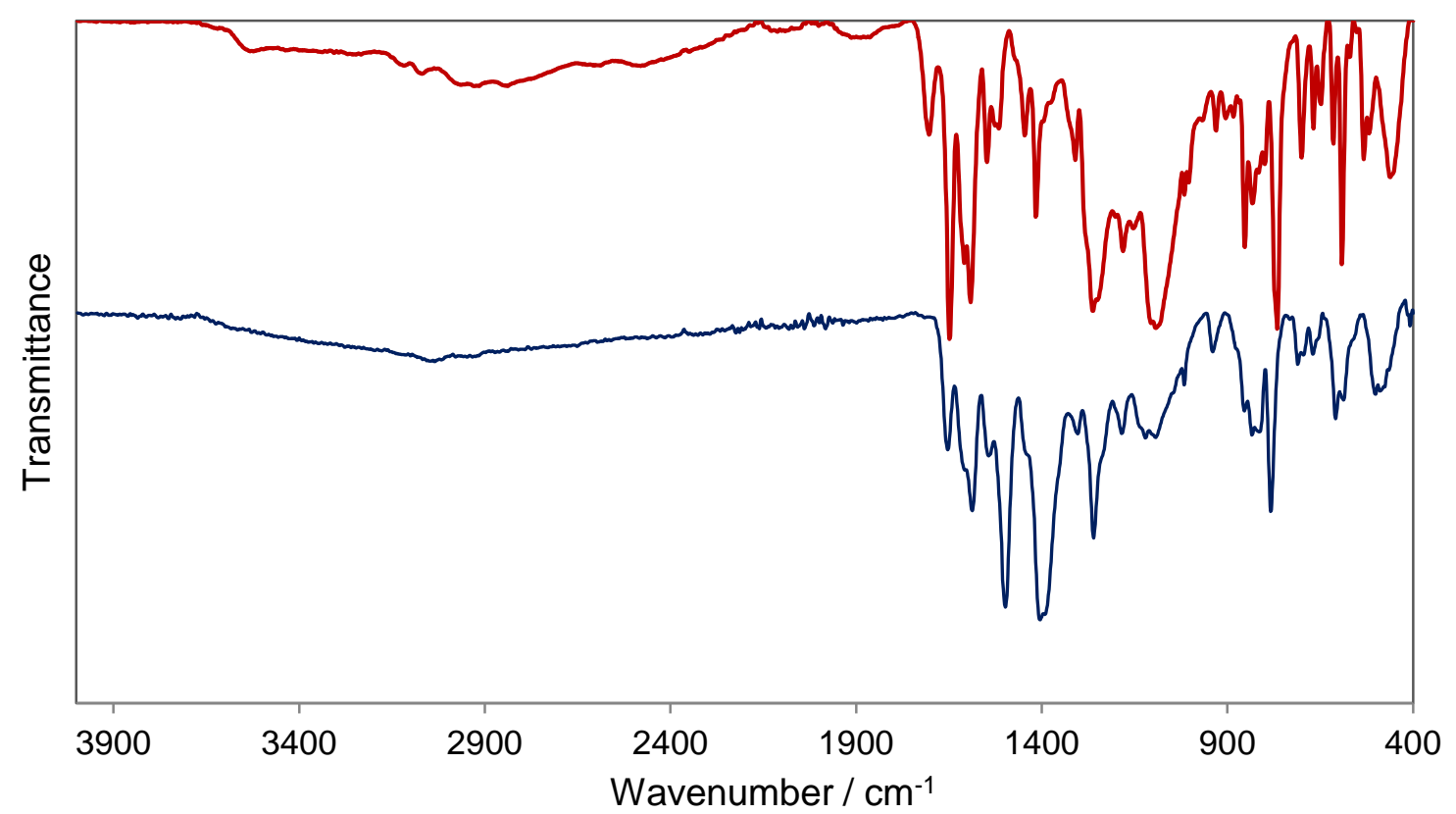

Figure S10. Infrared spectra of activated MOF-910 (blue) and heterotritopic linker PBCP (red) at room temperature.

Fourier-transform infrared spectroscopy verifies each of MOF-910's six ligating atoms is deprotonated. ${ }^{8}$ Specifically, absorption at $3530 \mathrm{~cm}^{-1}$ for the catechol O-H stretch is absent from the spectrum of the MOF as is the absorption at $3120 \mathrm{~cm}^{-1}$ for the pyridone N-H stretch. The absorption at $3070 \mathrm{~cm}^{-1}$ corresponding to the carboxylic acid $\mathrm{O}-\mathrm{H}$ stretch is also significantly reduced in intensity in the MOF spectrum compared to that of the linker. The absence of the absorption at $1700 \mathrm{~cm}^{-1}$ originating from the pyridone $\mathrm{C}=\mathrm{O}$ stretch in the spectrum of the MOF suggests the pyridone moiety is coordinated. The strong absorption at $1500 \mathrm{~cm}^{-1}$ in the spectrum of MOF-910 yet absent in that of the linker is attributable to the $\mathrm{C}=\mathrm{O}$ stretch of a semiquinonate ${ }^{9}$ and indicates oxidation of the linker occurs during the MOF synthesis. 


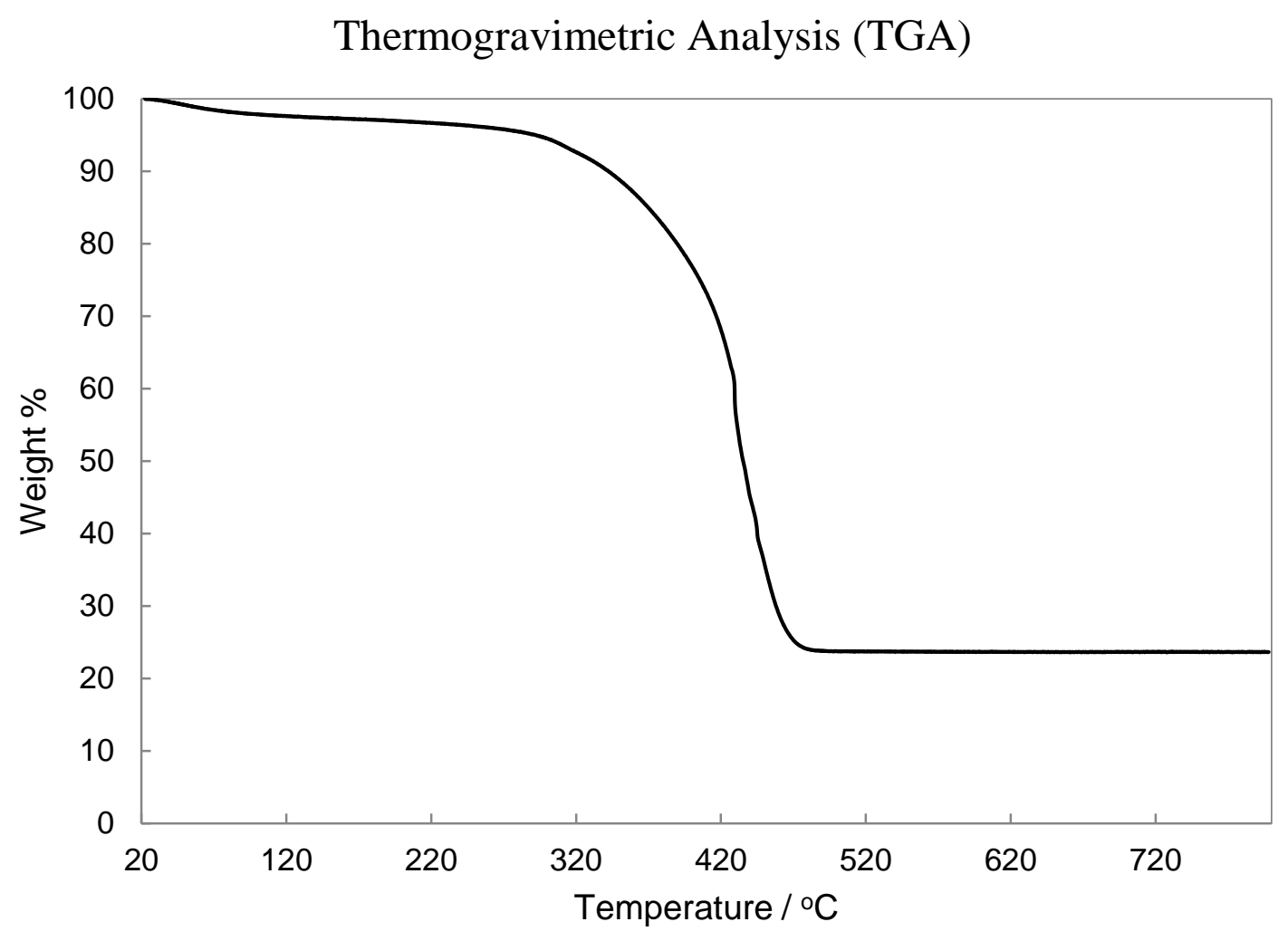

Figure S11. TGA trace of MOF-910 with a heating rate of $5{ }^{\circ} \mathrm{C}$ per minute measured in air.

Thermogravimetric analysis measured in air demonstrates MOF-910's high thermal stability and supports the structural assignment. The weight loss of $6 \%$ that begins near $100{ }^{\circ} \mathrm{C}$ corresponds with the chemical formula determined by elemental analysis in which two water molecules are present for each linker. The presence of a minimal amount of water is expected based on the observation of a single site of electron density within the hydrogen bonding distance of the free carboxylate oxygen of the disordered benzoate in the asymmetric unit. This single site of electron density likely belongs to a water molecule but could not be modeled due to the resolution of the data. After liberation of water, no significant weight loss occurs until $320^{\circ} \mathrm{C}$ which suggests the material contains no guests within the pores. The residual metal oxide weight of $23.6 \%$ agrees well with the expected value of $23.1 \%$ based on the chemical formula. 


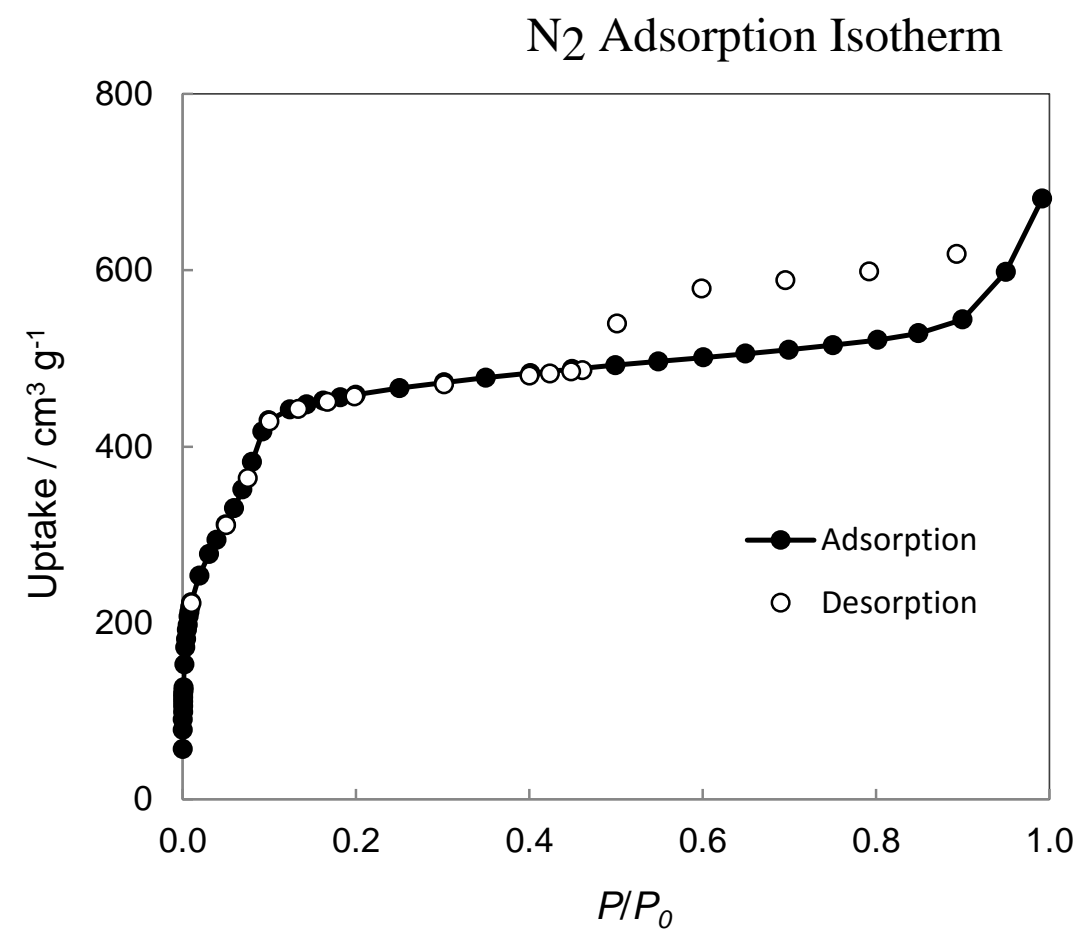

Figure S12. $\mathrm{N}_{2}$ sorption isotherm of MOF-910 at $77 \mathrm{~K}$.

The type H4 hysteresis loop likely results from interparticle voids present in the MOF-910 bulk powder sample. ${ }^{10}$

Pore Size Distribution

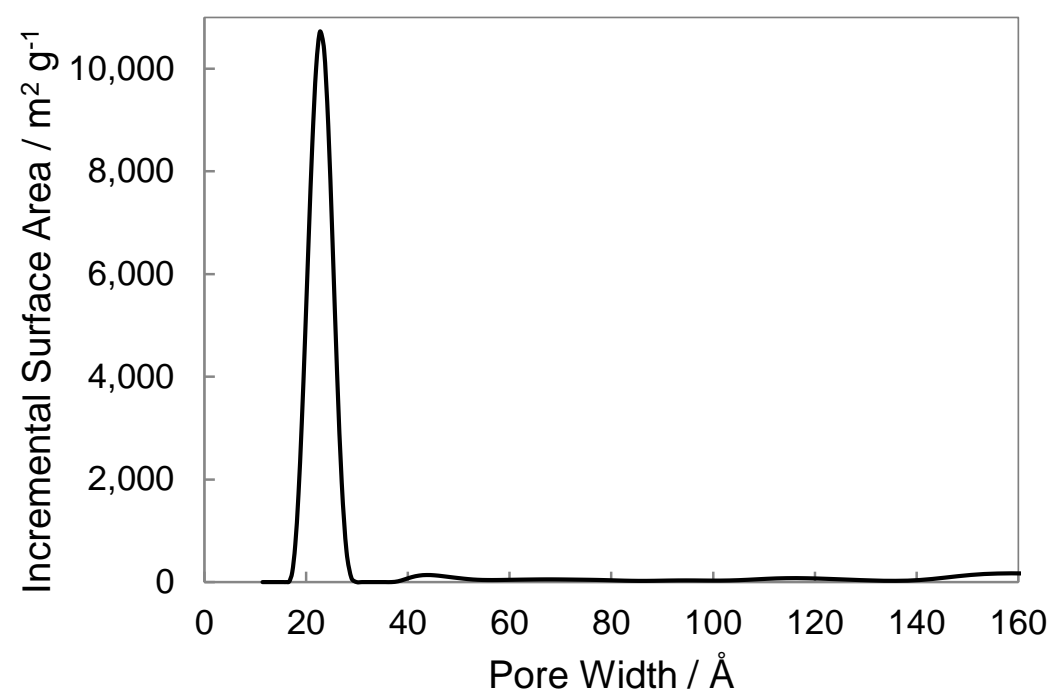

Figure S13. Pore size distribution calculated from $\mathrm{N}_{2}$ adsorption isotherm data points measured at $77 \mathrm{~K}$ based on the quenched solid state density functional theory (QSDFT) model for cylindrical pores. 


\section{Multi-point BET Surface Area Plot}

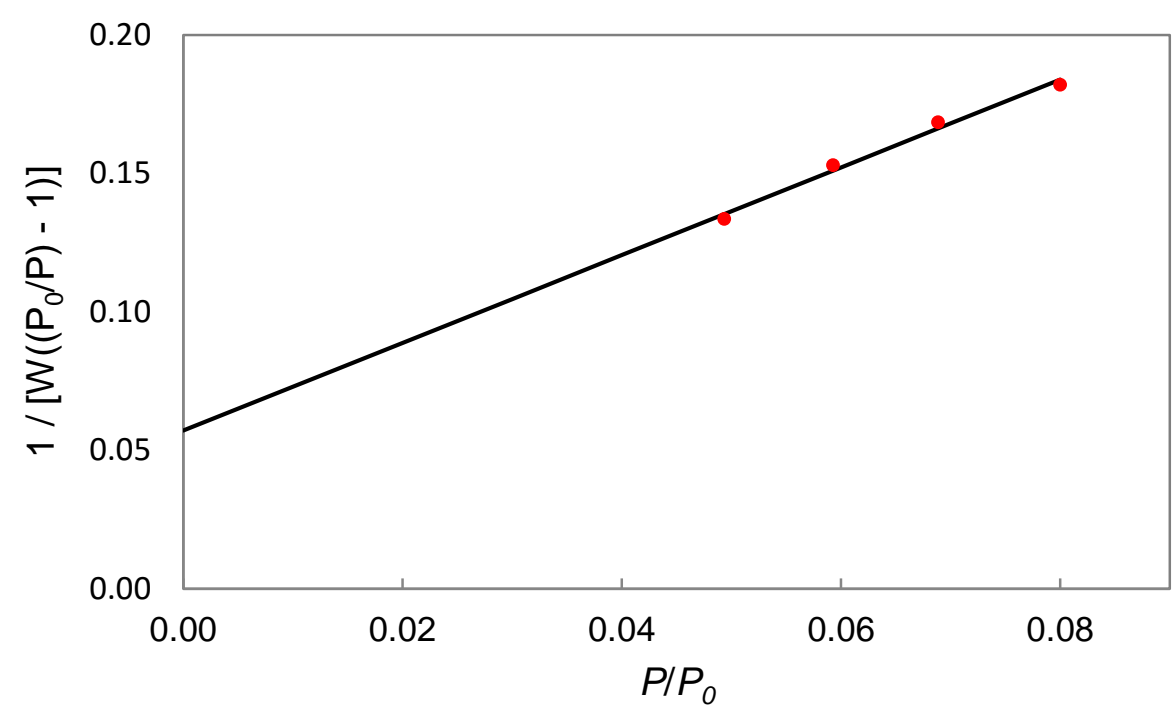

Figure S14. Plot of BET equation (black) and experimental $\mathrm{N}_{2}$ adsorption isotherm data points chosen for BET surface area calculation (red).

From this plot was derived a BET surface area of 2,123 $\mathrm{m}^{2} / \mathrm{g}$. The correlation coefficient, $\mathrm{r}$, for the fit is 0.9941 .

\section{Optical Microscopy}

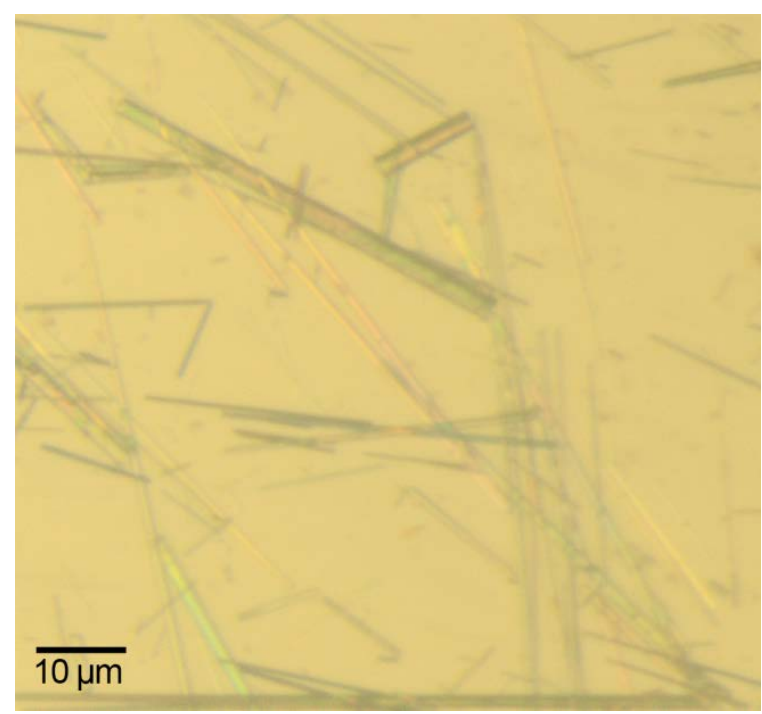

Figure S15. Optical microscopy image of MOF-910 crystals. 


\section{References}

(1) SADABS-2014/5, Bruker AXS, Madison, WI, USA, 2014.

(2) G. M. Sheldrick, Acta Crystallogr. Sect. A 2015, 71, 3.

(3) APEX3 v2015.5-2, Bruker AXS, Madison WI, 2005-2015.

(4) G. M. Sheldrick, Acta Crystallogr. Sect. C 2015, 71, 3.

(5) O. V. Dolomanov, L. J. Bourhis, R. J. Gildea, J. A. K. Howard, H. Puschmann, J. Appl. Crystallogr. 2009, 42, 339.

(6) F. H. Allen, O. Kennard, D. G. Watson, L. Brammer, A. G. Orpen, R. Taylor, J. Chem. Soc., Perkin Trans. 2 1987, 12, S1.

(7) B. Rees, L. Jenner, M. Yusupov, Acta Crystallogr. Sect. D 2005, 61, 1299.

(8) (a) Matsuda, Y.; Ebata, T.; Mikami, N. J. Phys. Chem. A. 2001, 3475. (b) Wilson, H. W. Spectrochim. Acta Part A Mol. Spectrosc. 1974, 30 (12), 2141. (c) Deacon, G. B.; Huber, F.; Phillips, R. J. Inorganica Chim. Acta 1985, 104 (1), 41.

(9) Min, K. S.; Dipasquale, A. G.; Rheingold, A. L.; White, H. S.; Miller, J. S. J. Am. Chem. Soc. 2009, 131, 6229.

(10) (a) Vishnyakov, A.; Ravikovitch, P. I.; Neimark, A. V; Bu, M.; Wang, Q. M. Nano Lett. 2003, 3 713. (b) Lowell, S.; Shields, J. E.; Thomas, M. A.; Thommes, M. Characterization of Porous Solids and Powders: Surface Area, Pore Size and Density. Springer Publishing: Dordrecht, The Netherlands, 2006. 